TECHNICAL TRANSACTIONS 7/2017

CZASOPISMO TECHNICZNE 7/2017

ARCHITECTURE

DOI: $10.4467 / 2353737$ XCT.17.105.6646

\author{
Eliza Szczerek (eszczerek@pk.edu.pl) \\ Division of Public Spaces for Movement, Institute of Urban Design, \\ Faculty of Architecture, Cracow University of Technology
}

\title{
INTERNATIONAL STUDENT WORKSHOPS AS AN IMPORTANT ELEMENT \\ IN ARCHITECTURAL EDUCATION
}

MięDZYNARODOWE WARSZTATY STUDENCKIE

JAKO ISTOTNY ELEMENT EDUKACJI ARCHITEKTONICZNEJ

\begin{abstract}
Workshops as one of the paths in the process of architectural education seem to constitute an important element in the development of competence and skills, mostly of students, but they can also considerably enrich the didactic and scientific competence of people who assume the role of teachers. This pertains especially to students of Ph.D. courses, who, as teaching assistants, are standing at the threshold of their teaching careers. Due to the fact that workshops have a different character than the formula of course projects, on the one hand, they are a diversion in the regular courses, and on the other, they enrich them to a considerable extent, especially if they are international.
\end{abstract}

Keywords: international students workshops, architectural education

\section{Streszczenie}

Warsztaty, jako jedna ze ścieżek w procesie edukacji architektonicznej, mogą stanowić istotny element rozwoju kompetencji i umiejętności studentów, ale także mogą wzbogacić warsztat pracy dydaktycznej i naukowej osób, które występują w roli prowadzącego. Dotyczy to szczególnie słuchaczy studiów doktoranckich, którzy jako asystenci stoją u progu swojej kariery dydaktycznej. Warsztaty studenckie, ze względu na swoją odmienną formę w stosunku do formuly projektów kursowych, stanowią niejako ich uzupełnienie. Z jednej strony są odskocznią od regularnego trybu studiów, a z drugiej w znaczący sposób mogą go wzbogacić, szczególnie jeśli ich charakter jest międzynarodowy.

Słowa kluczowe: międzynarodowe warsztaty studenckie, edukacja architektoniczna 
Workshops as one of the paths in the process of architectural education seem to constitute an important element in the development of competence and skills, mostly of students, but they can also considerably enrich the didactic and scientific competence of people who assume the role of teachers. This pertains especially to students of Ph.D. courses, who, as teaching assistants, are standing at the threshold of their teaching careers.

Due to the fact that workshops have a different character than the formula of course projects, the former, as it were, supplement the latter, and constitute an important element in the process of architectural education. A feature that makes workshops stand out is, above all, the working time, which is much shorter, translating into the manner and nature of work. Workshops most often last several days and predominantly focus on the development of guiding ideas. The works usually are performed in teams, which implies the need of close and intense cooperation between participants.

Both properly conducted workshops and course projects develop the skills and knowledge necessary to exercise the profession, which are referred to as the so-called hard competence, and the so-called soft competence, connected with personal psychophysical properties and interpersonal predispositions.

It seems that the difference between both forms of teaching resides predominantly in the extent to which a specific type of skills is developed. The curriculum of the university courses composed as a whole aims at guiding students through its individual stages, so as to allow them to develop the knowledge necessary to move on to the next one. Course projects, by 'guiding' to more and more complex issues, enable to obtain and consolidate students' knowledge and competence, focusing most of all on the development of the hard skills.

The formula of an architectural workshop is, on the one hand, a diversion in the regular courses, and on the other, it enriches them to a considerable extent. Most often, the tackled subjects pertain to up-to-date problems, which increases sensitivity to specific aspects, but also boosts the students' professional knowledge. The importance of this form of expanding knowledge of architecture students is well illustrated by the international workshop of Eco Rehab 3 - Future of the City (Cracow 2012 )ํㅡㄹ and 'Cracow Zakrzówek - Inner City Edge (Cracow 2013) ${ }^{2}$. Within the scheme of the Eco Rehab 3 workshop, the subject of housing estates consisting of buildings made of prefabricated concrete panels and options of their revitalization was tackled. The workshop devoted to Zakrzówek in Cracow focused on the issue of aggressive developers' policy in the city, in the context of creating the city edge, which is a place of contact between urbanized and green areas. Demographic and spatial problems of the currently poorly developing small Italian town were the subject matter of another equally valuable workshop: Canzo International Design Workshop (Canzo 2011) ${ }^{3}$.

1 International Student Workshop, Eco Rehab 3 - Future of the City. Workshop organized by the Institute of Urban Design, Faculty of Architecture, Cracow University of Technology, on 17-28 April 2012 in Cracow.

2 Workshop: Design Seminar 'Cracow Zakrzówek - Inner City Edge', organized by the Institute of Urban Design, Faculty of Architecture, Cracow University of Technology, on 15-17 November 2013 in Cracow.

3 Canzo International Design Workshop: projects for the touristic-environmental redevelopment of the Valassina district, held within the framework of a cycle of workshops "Territori in Evoluzione". It was held on 11-20.09.2011 in Canzo (Italy). 
The task of investigating the subject matter of a workshop, and later on of searching for a solution and development of the concept, requires strong commitment on the part of the students, as well as communication skills, creativity, dynamism of action, ability to work in a team, time management, etc. Therefore, it could be stated that workshops develop mostly the so-called soft skills to a great extent.

Workshops are also the time for the verification and utilization of the skills acquired so far. A short working time forces to act and make decisions quickly, as well as to organize oneself well. This calls for regular activities and closing subsequent stages 'step by step', securing constant progress. At this stage, an important role could be played by the group leader, who assists the team in going through subsequent stages of the project, moving them in the right direction.

For the team leader, it is also an opportunity to quickly confront and verify his/her teaching methods. A short duration of a workshop forces intensive work, thanks to which the effects of individual stages are visible on a constant basis. Therefore, workshops can also serve as a kind of experimental field where various approaches are tested.

A very important aspect of workshops is setting free and developing creativity. A characteristic and extremely important stage is brainstorming, which actually stands for setting abstract thinking free, overcoming limits, and verifying various variants of solutions, breaking the widespread preconceived notions. It is extremely important in the creative process, which, in case of students of architecture and urban planning, has a special significance. A valuable aspect of the operations of the teacher (team leader) could be the improvement of the team's sensitivity to adopting an appropriate operational strategy in the creative process. It is worth pointing out that the question 'how this could be done", especially in the initial designing phase, should not be dominated with questions 'what I want to do', 'what could be done here'. An inappropriate order can result in a blockade and become a barrier for creative thinking.

The most common workshop formula is teamwork. At the same time, it is an opportunity to develop the skill of presenting one's views, of defending them, of discussing ideas, as well as of reaching a consensus. Cooperation with other people broadens horizons and allows to perceive a specific topic from a different perspective.

Teamwork consists in the mutual symbiosis and allows to reach the effect of synergy. Individuals form a structure, where everybody is different and has their weaknesses and strengths. Therefore, it is important to diagnose the potential that resides in individual persons and to develop the strategy for benefitting from it so as to enable everybody to contribute. In this case, the role of the teacher can also prove to be helpful; the teacher can guide the team to secure synergy of the work of its members.

Teamwork and the feeling of belonging to a group constitute key elements that motivate a person to reach the target, which is the development of a specific solution. The feeling of isolation and lack of good relations hinders cooperation and reduces commitment. Therefore, it is important to take care of building relationship between team members, as well as creating appropriate atmosphere. A great role in this respect is played by additional activities beyond the workshop, aiming at socializing workshop participants. This allows to get to know each other, to establish closer relations, and in doing so, to build the feeling of belonging to the group. 
Additional socializing events, as well as lectures and meetings that accompany workshops, are also an important element of education, enabling to explore the subject matter. In case of the workshop held in Goerlitz ${ }^{4}$, where the main tool of the students of architecture was film, one of the most important elements of the workshops were meetings with employees of the Bablesberg movie studio in Berlin and visiting this facility. The movie studio has produced numerous distinguished masterpieces of film art, such as e.g. The Cabinet of Dr. Caligari (1920) or Metropolis (1927), as well as contemporary movies, such as V Like Vendetta (2006) or Inglourious Basterds (2009). The goal of the workshop was to create a several minutes' film illustrating the dichotomy of the city that functions on both sides of the border: Goerlitz - Zgorzelec, presenting its spatial aspects connected with its urban development. Examining the issues of a double city, grasping its everyday life and complicated past, required thorough investigation. Therefore, a very important item on the agenda was participation of the workshop attendees in a lecture devoted to the history of the city, as well as experiencing it physically. Visiting its nooks and spending time with its residents became a valuable source of inspiration.

A similar assumption connected with additional activities accompanied the INTBAU workshop ${ }^{5}$, the main idea of which was to investigate the principles of traditional and contextual design. Emphasis on designing in a strictly defined historical and cultural context most of all calls for thorough investigation and knowledge of the local building tradition. In order to understand these issues better, within the scheme of the workshop, a study visit to Zakopane was organized - a city of rich history and culture, with a strong identity of building and architecture. Besides experiencing the city and learning about its history, the workshop participants had an opportunity to learn about traditional craftsmanship, as well as about contemporary methods applied in the traditional building process. It aimed at the improvement of sensitivity to the aspect of tradition and context in the designing process so as to start to design space, which requires such an approach. The obtained knowledge and inspirations became the foundation for undertaking the main topic of the workshop, which is the development of a spatial concept for Sikorskiego Square in Cracow. Placing the workshop in a tenement house located at the square, as well as meetings with experts, allowed to fathom the knowledge about the history of this place, as well as to experience it more personally. Talks with the local community also proved to be very helpful. As a result, two valuable proposals of spatial solutions came into being. One was more traditional in its style, and the other was more contemporary in its form, both strongly connected with the context and referring to the historical conditions of the place.

Workshops that are international in character additionally enrich the path of the development of architectural education of students, as well as of their teachers. Working with people from various cultural environments is a form of approaching the problem from a different perspective.

4 City and a Film - Zgorzelec - Goerlitz - Workshop for Students in Architecture and Urban Design. 20-28 September 2013; organized by HAWK Hildesheim (Germany) and CUT Krakow (Poland) on 20-28 September 2013 in Goerlitz.

5 International training workshop devoted to contextual design and place creation, organized by INTBAU Polska and the Cracow University of Technology, in cooperation with INTBAU Italia and the Allerhand Institute on 8-16 May 2014 in Cracow. 
Functioning in a specific community defines certain patterns of behaviour, ways of thinking and approaching a given problem, and this in turn imposes a specific optics of perception, which easily becomes a strongly subjective point of reference. Cooperation with persons from other cultures allows to change this perspective and to see elements, which so far have been absent from one's own cultural references. This is particularly important with regard to a specific new place and space. People 'from the outside', with a different perspective and experience, are able to perceive a specific place in a different way. They can notice different values, different characteristic features, different relations, different connections embedded in them.

For a Ph.D. candidate, working in an international environment is a perfect opportunity to develop his/her teaching skills. Contact with people representing various schools has a considerable importance here, as they often demonstrate different approaches and philosophies in the process of teaching and project management. For the teaching staff, workshops are also a forum for the exchange of experience and an opportunity to observe one another, thanks to which everyone can learn something new and introduce new elements to their working methods. It is important for Ph.D. candidates because they can improve their teaching skills considerably in a short time. It also pertains to the ways of integrating a team, of motivating students, as well as of organizing team work and assuming a substantive approach to the subject matter. Numerous matters that are important for the teacher can be provided by students themselves, whom, being educated at different universities, present different ways of thinking. Contact with a different perspective and optics of perceiving the ways of developing the skills of creative activities of students constitutes a very important experience for the teacher, and for Ph.D. candidates in particular, as it allows them to get to know the diversity of approaches to this issue right at the beginning of their teaching career.

International cooperation also stands for the exchange of experience in a similar field. The Eco Rehab 3 workshop focused on housing estates consisting of buildings made of prefabricated concrete panels, which is a topic that most European cities, especially from the former Eastern Bloc, have been familiar with. The workshop became an arena for the exchange of thoughts and experience connected with them, and for the joined search for ways to revitalize them. It pertained to the design and spatial solutions for specific housing estates in Cracow, located in Czyżyny, in the vicinity of a former runway. Students from Italy, Spain, Romania, Germany and Poland were looking together for ways to create attractive public spaces in the housing estate. Their work resulted in the formulation of 8 concepts for the development of this area, and the diversity of the developed concepts demonstrated a number of possibilities of interpreting this place and its solutions. The designs were strongly founded in the context of the city and were taking the specificity of the place into account. However, despite this fact, due to the nature of this type of urban formations, it was possible to find certain universal solutions for them. The workshop constituted a perfect place for the exchange of observations and mutual inspiration of students, as well as the teaching staff. The comments of the jurors proved to be very valuable, too.

The examples listed above demonstrate that workshops enable to obtain and develop skills, which are necessary in the professional activities of an architect or an urban planner. One of the necessary skills is cooperation with specialists from a related, but not the same field, as in 
fact working on a design usually comprises multi-faceted activities, especially in case of urban design, which requires comprehensive strategies. Design workshops with the participation of students from different specialties enable them to cooperate and look for solutions to problems on numerous planes. Such a formula was adopted during a double edition of the CracowVienna workshop ${ }^{6}$. The subject matter of the study was an area located within the borders of Zakrzówek, limited from the north and east by the Vistula River, and from the south and west by the route of the planned Relief Channel. The cooperation of students from Cracow from the majors of Architecture and Urban Planning, as well as from the Technical University of Vienna, predominantly from the major of Spatial Planning, resulted in the development of four interesting concepts of the development of this area. One of them pertained to its development in the context of Cracow as the capital of culture in 2020. The starting point for adopting an appropriate strategy for its selected area was confronting the immense potential of Cracow, resulting from its historic and cultural heritage, with the needs of the contemporary knowledge society. In this respect, there appeared concepts that gave rise to a more detailed planning of this area. It was assumed that the city should develop as a dynamic complex structure. The historic city should be an integral part of the entire urban structure of the city, and not a mummified reserve. In this respect, changes that occur in historic cities should be based on the constant search of balance, harmony and compromise between the economic reality and the principles pertaining to the integrated approach to heritage protection.

As a result, there appeared a concept according to which the area of Dębniki was to become a new stage for arts, culture and knowledge. This area offers a lot of opportunities and freedom of operation and experimenting, unlike the historic tissue of the city, which naturally imposes numerous architectural and urban limitations. There is more space for innovative activities and experiments, maintaining a great potential of this terrain: there are areas located close to the city centre and, at the same time, areas, which exhibit a diversified structure, combining attractive green areas with a water reservoir and developed areas of a different character.

Cooperation of students of architecture and urban planning with students of spatial planning also allowed to develop a concept of the spatial development and a development strategy for these areas. Operations were divided into 2 stages; key activities necessary to be performed by 2016, and then by 2020, were described.

A very interesting and instructive form are workshops which consist in the cooperation of students of the $1^{\text {st }}$ and $2^{\text {nd }}$ degree courses, students of Ph.D. courses and professors, during which all participants work together and develop a common concept. It is close to the formula of working in an architectural office, which could be a valuable experience for students. The teacher does not act as an outsider who only evaluates, but he/she actively participates in the designing process. This formula was adopted in the aforementioned workshop devoted to the area of Zakrzówek in Cracow. Its goal was to create the city edge, which is a place of contact of green and urban areas. For the city of Cracow, this subject is particularly sensitive because there are very attractive areas due to their natural and recreational value. At the same

6 Vienna-Cracow International Design Workshop, organized by the Institute of Urban Design, Faculty of Architecture, Cracow University of Technology, and TU Wien; $1^{\text {st }}$ edition: 8-12 September 2010 (Cracow), $2^{\text {nd }}$ edition: 16-22 May 2011 (Vienna). 
time, they are under a great pressure of developers. The goal of the workshop was to find a compromise solution that would maintain the green character of this space, but which simultaneously would enable to introduce a safe investment there, which is an investment that would not have any effect on the degradation of these areas. The final effect had a form of 5 concepts demonstrating different possible solutions.

An interesting approach to the organization of workshops is the issuance of topics to be developed by students prior to the commencement of the workshop. In such an event, the workshop begins with thematic presentations prepared by students. This allows not only to fathom the subject matter more quickly and efficiently, but also to get to know the predispositions of persons who are to cooperate. Opportunities offered by the Internet communication enable us to cooperate with people from different parts of the world; geographical distance is not an issue any more. In case of the 'Goerlitz - Zgorzelec' workshop, the pre-workshop work resulted in a thematic foundation of the workshop in the form of presentations pertaining to the town, as well as to the history of cinema.

Within the Eco-Rehab workshop, a formula of earlier preparation of presentations connected with the set topics was also adopted. The attending students from different European universities presented the problem from the point of view of their countries. The task faced by students from Cracow, where the workshop was held, was to conduct thorough analyses of the place that was the subject of the workshop - housing estates consisting of buildings made of prefabricated concrete panels in Czyżyny. The analyses presented during the public presentation, as well as the studies published as brochures, were to be the basis for further exploration of the area and its problems and for finding a concept for its development.

Due to the limited working time compared to semester projects, the workshop studies devoted to architectural and urban issues are most frequently focused on communicating a concept and an idea. This pertains especially to more complex large-scale designs. Therefore, it frequently happens that a workshop is a starting point of a course project conducted later on. They constitute a perfect substantive foundation for them, but, at the same time, they serve as a kind of exercise for further designing activities.

For Ph.D. candidates, architectural workshops are not merely a valuable experience from the point of view of teaching, but they can also become a sort of a field for inquiries for their research work. As far as the author of this commentary is concerned, it referred to e.g. the topic of architecture made of prefabricated concrete panels, which is the subject of her Ph.D. dissertation. Her participation in the Eco-Rehab 3 workshop, which was fully devoted to this kind of architecture, and in the Cracow-Vienna workshop, which touched upon this issue as well, although to a lesser extent, allowed most of all to confront the adopted approach to this research topic with concepts of students, sometimes too abstract, but usually fresh, created with considerable imagination. The discussion demonstrated that students' concepts and solutions could be beneficial for creative verification of proposed solutions to a given problem. In this case, the emphasis was put on the role of revitalization of such housing estates in the creation of continuity and complementarity of public spaces in the city. Selected housing estates in Cracow became a field of the search for new forms of space of a housing 
estate, taking into account the context of the place and its values, as well as its affiliation with the system of urban spaces.

Due to the fact that there constantly emerge new opportunities of cooperation between universities or their individual units, within the scheme of international programmes, bilateral agreements, etc., workshops, especially over the last few years, have become a more and more popular and common element in the process of architectural education. Their number, and at the same time their diversity in the sense of the adopted formula or subject matter, provides students as well as Ph.D. candidates with an opportunity to choose the ones that seem to be the most useful and close to their interests. It is particularly important for $\mathrm{Ph} . \mathrm{D}$. candidates, since besides developing their teaching skills, they can also support their scientific research.

The author's experience gained so far proves that workshops can play a significant role in the process of architectural education of students. They also offer new knowledge to the teaching staff, especially to young academics, both in terms of the methodology of teaching and creative discussions devoted to the research problems solved by them. Regular participation in workshops, which nowadays is becoming more and more possible due to their multitude, allows to constantly improve one's teaching competence. Furthermore, in the knowledge society, characterized by a quick information flow, the possibility of moving around, and generally speaking a more mobile lifestyle, contact with representatives of other cultures and expanding one's thinking horizons by confronting experiences in the international environment constitute very important aspects of development for people who study and are engaged in scientific activities.

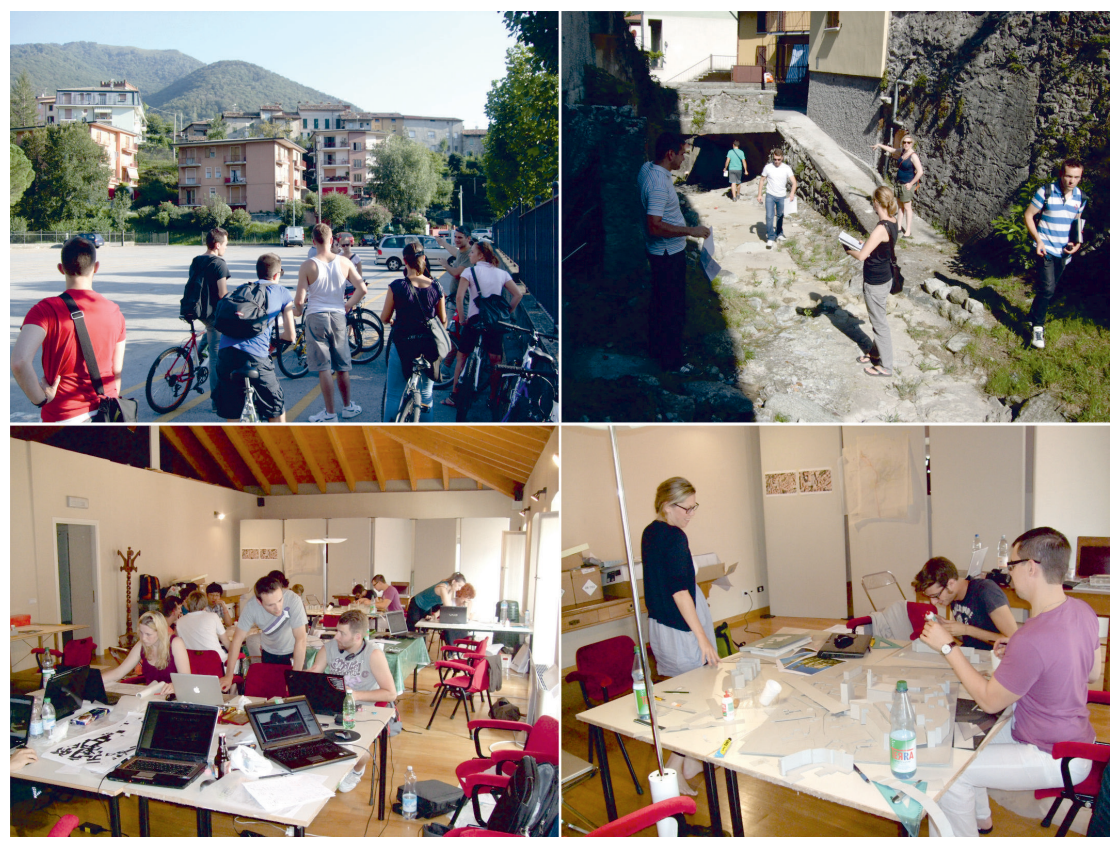

Fig. 1. Different activities within Canzo International Design Workshop - "Territori in Evoluzione" (11-20.09.2011, Canzo, Italy): bike tour around the town, site visit, working in studio 

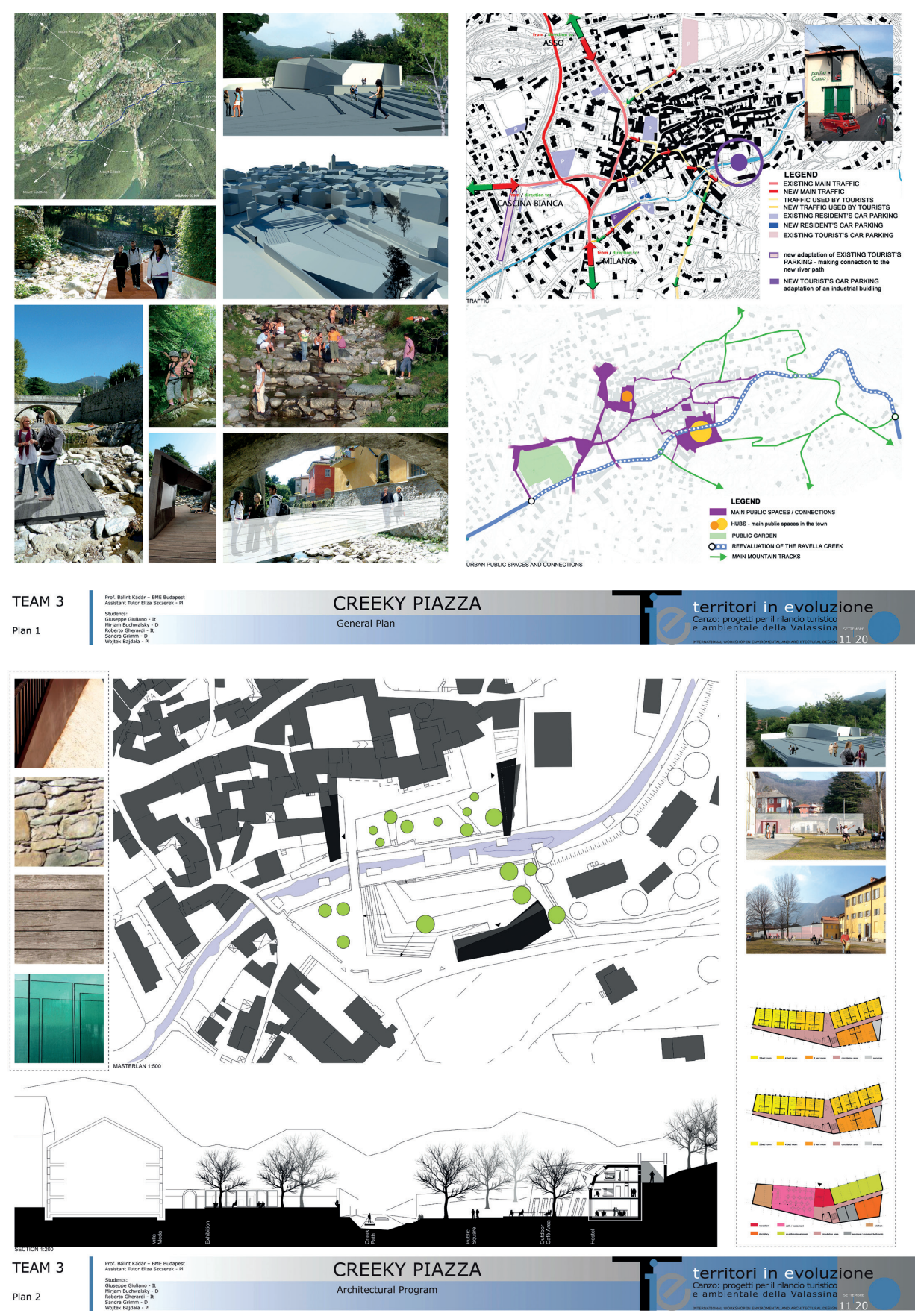

Fig. 2, Fig. 3. Final presentation boards of Team No. 3 (Students: Giuseppe Giuliano - IT, Roberto Gherardi - IT, Mirjam Buchwalsky - DE, Sandra Grimm - DE, Wojtek Bajdała - PL; Tutor: Bálint Kádár - HU, Tutor Assistant: Eliza Szczerek - PL); Canzo International Design Workshop - "Territori in Evoluzione” (11-20.09.2011, Canzo, Italy) 


\section{References}

[1] M. Gyurkovich (ed.), Future of the city. Mass housing estates of multifamily housing complexes?, Eco Rehab 3, Kraków 2012,

[2] Szczerek E., Adjusting Prefabricated Housing Estates to Contemporary Conditions and Local Specificity in Revitalization Processes-German Experiences, „Future of the city. Mass housing estates of multifamily housing complexes?”, Eco Rehab 3, Kraków 2012, M. Gyurkovich (ed.), p. 128-135.

[3] Szczerek E., Discovering the city and placemaking. Canzo case study, 6 ULAR : The Urban Landscape Renewal: City-People Friendly Places: ideas-projects-realisations: proceeding of International Scientific Conference Silesian University of Technology: monograph. Vol. 2, N. Juzwa, A., Sulimowska-Ociepka (eds.), Gliwice 2012, p. 387-392.

[4] Fredriksson U., Quality Education: The Key Role of Teachers, Education International Working Papers No. 14, September 2004; http://glotta.ntua.gr/posdep/Dialogos/ Quality/ei_workingpaper_14.pdf (access: 04.05.2017). 